\title{
Corporate Social Responsibility Practices of Commercial Banks in India
}

\author{
Nithin Venugopal ${ }^{1}$ and Benson Kunjukunju ${ }^{2 *}$ \\ 'Research Scholar, Post Graduate and Research Department of Commerce, St. Thomas College, Kozhencherry, Kerala, \\ India \\ ${ }^{2}$ Research Guide, Post Graduate and Research Center in Commerce, St. Thomas College, Kozhencherry, Kerala, India; \\ bensonkunjukunju@gmail.com
}

\begin{abstract}
Corporate Social Responsibility (CSR) of a business yields welfare measures to the society. The word "responsibility" calls for moral obligations towards the society. Now-a-days CSR has drawn commendable significance in the corporate world including banking sector. Commercial Banks in India are occupied a lot of operations which they showcase as their contribution in terms of Corporate Social Responsibility (CSR). The CSR activities of banks have gained further importance in the wake of new listing guidelines issued by Securities and Exchange Board of India (SEBI) and on the introduction of Companies Act 2013. The main objective of this article is to make a study on the perception of employees and beneficiaries of the CSR initiatives regarding the major issues that they feel that the bank should take up on priority basis. Further the theoretical aspects of Corporate Social Responsibility (CSR) in commercial banking have also been exposed along with the actual spending by Indian commercial banks for CSR activities during the financial years 2014-15 and 2015-16.
\end{abstract}

Keywords: Business Responsibility Reporting, Commercial Banks, CorporateSocial Responsibility (CSR), Social Responsibility

\section{Introduction}

The term 'Corporate Social Responsibility' (CSR) became a normal usage in the late 1960 s and early 1970 s after numerous Trans National Corporations (TNCs) coined the term 'Stakeholders', which means those on whom an organisation's activities have an impact. In spite of the fact that the idea of CSR is in vogue for more than three decades, a generally accepted definition of CSR is still unavailable to capture the elements and dimensions of CSR. According to the United Nations Industrial Development Organization (UNIDO), "Corporate Social Responsibility is a management concept whereby companies integrate social and environmental concerns in their business operations and interaction with their stakeholders"

CSR has assumed commendable significance in the corporate world, and the banking sector is no exception. The financial sector has inclined to promote environmentally friendly and socially responsible lending and investment practices. Taking deposits, giving advances and extending related services are the prime activities of banks. As a socially responsible bank, it needs to exert legitimate banking practice, cautiously and efficiently with close monitoring of transactions to enhance customer confidence under buoyant economic conditions. Almost all corporate websites/policies/brochures and reports talk about their CSR endeavours which have become a way of ensuring that companies are fulfilling their obligations towards society at large.

In the Indian banking sector, the documentation of CSR initiatives was negligible until recently. But now, a number of banks have given a fillip to this move. Commercial banks in India have taken up CSR activities seriously as the Reserve Bank of India has advised all the commercial banks operating in India to set aside at least one per cent of their profits for CSR activities.

*Author for correspondence 
A lot of studies were made to know the status of CSR implementation among corporate world across the globe and Indian corporate sector. But only a few studies were made in respect of CSR implementation in the Indian banking sector.

The scenario in respect of CSR is changing in India rapidly. The enforcement of new Companies Act 2013 and stipulation of new guidelines by SEBI have given CSR activities and its reporting a new face lift by making it mandatory rather than a voluntary action.

\section{CSR in India - Legality}

\subsection{Companies Act 2013}

The Ministry of Corporate Affairs (MCA) disseminated guidelines for CSR on voluntary basis in 2009, which were incorporated to obtain legal sanctity within the Companies Act 2013, U/S 135 making it mandatory for companies a net worth of Rs. $500 \mathrm{Cr}$ or more, or a turnover of Rs. $1000 \mathrm{Cr}$ or more, or a net profit of Rs. 5 Cr or more, during any financial year and should establish CSR Committee comprising three or more directors, out of which, at least one should be an independent director, and the same be included in the Board's Report ${ }^{2}$. The committee can frame policies and activities specified in Schedule VII.

Further, companies should spend at least $2 \%$ of the average net-profits of the immediately preceding three years on CSR activities, otherwise explanation be given in the Director's Report. These rules will be applicable from F.Y. 2014-15 onwards, which can be discharged in the ways mentioned below:

- Setting up its own non-profit foundation to facilitate this initiative.

- (Eg. ICICI Foundation, ING Vysya Foundation, Axis Bank Foundation etc. )

- By way of independently registered non-profit organisations that have a track record of 3 years in similar activities.

- Pooling resources with other companies.

\subsection{SEBI Requirements}

The other reporting requirement is the one enforced by Securities and Exchange Board of India (SEBI) through a circular on August $13^{\text {th }} 2012^{3}$. It requires that all listed companies and those which wish to get its shares listed shall report its CSR activities in the form of Business Responsibility Report (BRR) forming part of its annual report. SEBI has developed a template for filing BRR.

\section{Review of Literature}

Ankita Patel (2016) $)^{4}$, attempted to study and compare the CSR activities of leading commercial banks in India. Sharma and Agarwal (2016) $)^{\frac{5}{5}}$ analyzed the CSR practices of select public and private sector banks in India and concluded that $2 \%$ share of profits was not spent on CSR. Carolin Juliya Pushpam V., Karthi R. and Asha Daisy B. (2015) 6 exposed the fact that the standards for rating CSR practices are more inconsistent in comparison to that of financial rating, which therefore hinders comparison. Eliza Sharma and Mukta Mani (2013) $\frac{7}{7}$ have asserted that the public sector banks have placed on record the overall highest contribution in CSR activities, while the private sector and foreign banks are still lagging behind. Paul and Onyema (2012) $)^{8}$ investigated the effect of CSR on Banking Performance in Nigeria. Yeung $(2011)^{9}$ explored the perception of respondents on CSR and banking practice of major banks in Hong Kong. Kostyuk et al. (2011) ${ }^{10}$ made an overview of CSR among banks in different countries. Khan, Md. H. U. Z., Habib (2010) 11 investigated the CSR reporting information of listed commercial banks in Bangladesh and exposed the potential effects of corporate governance elements on CSR disclosures.

\section{Objectives}

a) To bring out the CSR activities including the major areas of focus by the select commercial banks in India.

b) To show the pattern of CSR expenditure among the select Indian Commercial Banks.

c) To identify the differences between the perception level of bankers and that of beneficiaries relating to CSR activities.

\section{Research Methodology}

Both primary and secondary data were employed for the study. Secondary data were gathered from annual reports, review of CSR, journals, Banks' websites, Banks' Publications, newspapers and online databases.

For the purpose of collection of primary data, Indian commercial banks were classified into four groups viz., State Bank of India, Nationalised Banks, Old Private Sector Banks and New Private Sector Banks. One bank from each group was randomly selected for the study which is as follows:

- State Bank of India (SBI)

- Union Bank of India (UBI) among nationalized banks 
- Federal Bank Ltd. (FB) among old private sector banks

- HDFC Bank among new private sector banks

In case of primary data on CSR initiatives, questionnaire was used to collect information from the employees of the select banks and interview schedule was used for collecting information from the beneficiaries. The study was conducted at three major cities of South India namely Cochin, Bangalore and Coimbatore from the state of Kerala, Karnataka and Tamilnadu respectively. One branch was selected randomly from each city in respect of the four select banks for the collection of information from both employees and beneficiaries. Thus, in total 12 bank branches were selected from three different cities of three states to constitute a total sample respondents of 360 bank employees and 120 beneficiaries.

\section{Period of Study}

The study covers a period of two financial years 2014-15 and 2015-16 since the CSR reporting was standardised from the F.Y. 2012-13 onwards and standardized data is available from the financial year 2014-15 only. Analytical, descriptive and comparative methodology has been adopted for the study.

\section{CSR Initiatives Undertaken by Sample Banks}

\subsection{State Bank of India}

State Bank of India carries out its CSR initiatives under the flagship SBI Foundation. The very objective of the Foundation is to promote growth, equality and responsiveness to the relevant needs of communities in which it operates.

SBI Foundation has identified several areas of intervention for the implementation of projects. These focus areas have been identified in line with and in alignment with the provisions of Schedule VII of Section 135 of the Companies Act, 2013. SBI's key focus areas of CSR are ${ }^{12}$ :

- Healthcare and Sanitation

- Education

- Skills and livelihood development

- Women empowerment and care for senior citizens

- Rural development

- Promotion of sports and arts

- Environmental conservation

\subsection{Union Bank of India}

The initiatives of Union Bank of India are developed in such a way that it ensures the overall development of community in which the bank exists. It carries out its CSR projects through its own foundation named Union Bank Social Foundation. The major focus areas of the CSR activities of UBI are $^{13}$ :

- Farmers Club that brings together farmers in villages in which the bank branch caters to and discusses the problems, solutions and new agricultural practices. The initiative has helped in overall adoption of better farming practices.

- Village Knowledge Centres (VKC) is another CSR project of the bank which serves as information dissemination centre providing access to farmers to the latest information and knowledge available in the field of agriculture starting from crop production to marketing.

- Union Mitr is a program by UBI which aims to give financial literacy to all layers of people. It helps in bringing about changes in savings and investment habits of people.

- Rural Self Employment Training Institutes

- Environmental conservation

- Conducting medical camps

- Village adoption

\subsection{The Federal Bank Ltd.}

Federal Bank Ltd. has approved a policy for sustainable development which ensures that bank's activities are conducive for sustainable social development.

The main area of bank's focus is education for the purpose of which it has set up Fedbank Hormis Memorial Foundation to inculcate better knowledge and awareness in the field of banking through training programmes, focused seminars, awards and so on. The other objectives of the foundation are establishing libraries and public information system related to banking, finance and economics. It has also established grants and scholarships to deserving students. Bank has the policy to serve every geographic area in India irrespective whether Federal Bank branch has operation or not.

Bank in its CSR policy has clearly stated that the Fedbank Hormis Memorial Foundation can also be used to carry out other CSR initiatives if needed. Federal Bank's major focus areas of CSR are ${ }^{14}$ :

- Healthcare and poverty alleviation

- Education and skill development 
- Gender equality and welfare of senior citizens

- Protection of national heritage

- Meeting the needs of differently abled people

- Promotion of sports and arts

\subsection{HDFC Bank}

HDFC Bank in its CSR Policy clearly states that CSR is not just confined to or does not mean charity or mere donations. According to the bank it is a way of going beyond the business, creating shared value and contributing to social and environmental good. HDFC mainly implements the CSR projects under the following target areas ${ }^{15}$ :

- Sustainable livelihood

- Financial literacy and inclusion

- Promotion of education

- Skill training and self-employment training

- Promoting blood donation

- Environmental sustainability

- Door step school

- Helpage India

- HDFC Bank carries out the projects through various partner foundations namely, Ashray-Akruti, Lend-A-Hand India, Masoom, Oxam India, Saath Charitable Trust, Child Aid Foundation and Watershed Organisation Trust.

\section{Pattern of CSR Spending by Select Banks}

Table 1 discloses the net Profit After Tax (PAT), corresponding expenditure in respect of CSR activities and its share in PAT in percentage of all the four select banks for the financial years 2014-15 and 2015-16.

Table 1 reveals that during the financial year 2014-15 SBI's PAT was the highest at Rs.13,102 crores, followed by HDFC at Rs.10,216 crores, UBI at Rs.1782 crores and Federal Bank at Rs.1006 crores. However, in terms of expenditure on CSR activities, HDFC had topped with Rs. 118.55 crores, followed by SBI with Rs. 115.80 crores, UBI with Rs.13.25 crores and Federal Bank with Rs.7.30 crores. Consequently, the CSR spending as percentage of PAT was pegged at $1.16 \%$ by HDFC as the highest, followed by $0.88 \%$ in case of SBI, $0.74 \%$ in case of UBI and $0.73 \%$ in case of Federal Bank.

When considering the financial year 2015-16, HDFC's PAT was the highest at Rs.12,296 crores, followed by SBI at Rs. 9951 crores UBI at Rs. 1,352 crores and Federal Bank at Rs.476 crores.It is to be noted that during 2015-16, all select banks except HDFC had booked a lower PAT than the previous year due to extensive provisioning towards NPA (Non Performing Assets) and high market volatility. In terms of expenditure on CSR activities, both HDFC and SBI had retained their position of being first and second by registering at Rs.194.81 crores and Rs.143.92 crores respectively. Whereas, the third position was clocked by Federal Bank with Rs.12.30 crores, leaving the UBI at the fourth place with Rs.6.98 crores. However, on the score of CSR spending as percentage of PAT, Federal Bank had stood first with $2.58 \%$ by spending even the unspent amount of the preceding year. This was followed by HDFC with $1.58 \%$, SBI with $1.45 \%$ and UBI with $0.52 \%$.

Table 1: Profit after Tax and CSR Spending

\begin{tabular}{|l|l|l|l|l|l|l|}
\hline \multirow{2}{*}{} & \multicolumn{3}{|c|}{ Financial Year 2014-15 } & \multicolumn{3}{c|}{ Financial Year 2015-16 } \\
\hline \multicolumn{1}{|c|}{ Banks } & $\begin{array}{c}\text { Profit after } \\
\text { Tax (PAT)(Rs. } \\
\text { in Crore) }\end{array}$ & $\begin{array}{c}\text { CSR } \\
\text { Expenditure } \\
\text { (Rs. in Crore) }\end{array}$ & $\begin{array}{c}2014-15 \\
\text { CSR } \\
\text { Expenditure } \\
\text { as a of Profit } \\
\text { after Tax }\end{array}$ & $\begin{array}{c}\text { Profit after } \\
\text { Tax (PAT)(Rs. } \\
\text { in Crore) }\end{array}$ & $\begin{array}{c}\text { Expenditure } \\
\text { (Rs. in Crore) }\end{array}$ & $\begin{array}{c}\text { Expenditure } \\
\text { as a of Profit } \\
\text { after Tax }\end{array}$ \\
\hline $\begin{array}{l}\text { State Bank of } \\
\text { India }\end{array}$ & 13,102 & 115.80 & $0.88 \%$ & 9,951 & 143.92 & $1.45 \%$ \\
\hline $\begin{array}{l}\text { Union Bank } \\
\text { of India }\end{array}$ & 1,782 & 13.25 & $0.74 \%$ & 1,352 & 6.98 & \\
\hline Federal Bank & 1,006 & 7.30 & $0.73 \%$ & 476 & 12.30 & $2.58 \%$ \\
\hline HDFC & 10,216 & 118.55 & $1.16 \%$ & 12,296 & 194.81 & $1.58 \%$ \\
\hline
\end{tabular}

Source: Annual Reports 


\subsection{Average Net Profit and CSR Spending}

Table 2 \& Table 3 shows the mandatory spending requirement by a banking company on CSR initiatives as specified in Schedule VII of the Companies Act 2013 against the actual expenditure on CSR initiatives in respect of all the four select banks. If a company fails to spend at least $2 \%$ of the average of the last 3 years' profit after tax, then as per the requirement under Section 135 every company is obliged to report as to why it has not spent the stipulated amount on CSR projects.

Table 2: Average Net Profit and CSR Spending for the Financial Year 2014-15

\begin{tabular}{|l|l|l|l|}
\hline Name of the Bank & $\begin{array}{l}\text { Average Net Profit of } \\
\text { Preceding 3 Years to } \\
\text { Financial year 2014-15 }\end{array}$ & $\begin{array}{l}\text { Amount to be Spent on } \\
\text { CSR Activities as Per } \\
\text { Sec. 135 }\end{array}$ & $\begin{array}{l}\text { Actual Spending in the Financial year } \\
\text { 2014-15 (as a of average profits of } \\
\text { three preceding years) }\end{array}$ \\
\hline State Bank of India & 12,234 Crore & 245 Crore & 115.80 Crore $(0.95 \%)$ \\
\hline Union Bank of India & 1,881 Crore & 38 Crore & 13.25 Crore $(0.70 \%)$ \\
\hline The Federal Bank Ltd & 818 Crore & 17 Crore & 7.28 Crore $(0.89 \%)$ \\
\hline HDFC Bank & 6,640 Crore & 133 Crore & 118.55 Crore $(1.79 \%)$ \\
\hline
\end{tabular}

Source: Computed from secondary data

Table 3: Average Net Profit and CSR Spending for the Financial Year 2015-16

\begin{tabular}{|l|l|l|l|}
\hline Name of the Bank & $\begin{array}{l}\text { Average Net Profit of } \\
\text { Preceding 3 Years to } \\
\text { Financial year 2015-16 }\end{array}$ & $\begin{array}{l}\text { Amount to be Spent on } \\
\text { CSR Activities as Per Sec. } \\
\mathbf{1 3 5}\end{array}$ & $\begin{array}{l}\text { Actual Spending in the Financial } \\
\text { year } \\
\mathbf{2 0 1 5} \\
\text { three preceding years) }\end{array}$ \\
\hline State Bank of India & 12,699 Crore & 143.92 Crore $(1.13 \%)$ \\
\hline Union Bank of India & 1,879 Crore & 254 Crore & 6.98 Crore $(0.37 \%)$ \\
\hline The Federal Bank Ltd. & 8,94 Crore & 18 Crore & 12.30 Crore $(1.38 \%)$ \\
\hline H.D.F.C Bank & 8,323 Crore & 166 Crore & 194.81 Crore $(2.34 \%)$ \\
\hline
\end{tabular}

Source: Computed from secondary data

In the F.Y. 2014-15 as per Table 2 SBI's actual expenditure on CSR projects amounted to Rs. 115.80 crores only, which was $0.95 \%$ of the preceding three years' average net profit as against its mandatory requirement of Rs. 245 crores on CSR projects. The same was the case with regard to UBI and Federal Bank lagging far behind the mandatory requirement by spending Rs.13.25 crores and Rs.7.28 crores respectively, which contributed to just $0.70 \%$ and $0.89 \%$ of their respective average net profit of the preceding three years. However, HDFC clocked $1.79 \%$ amounting to Rs.118.55 crores while it was supposed to spend Rs.133 crores on CSR activities for the year. Thus among the select banks, HDFC bank ranked first in CSR spending at $1.79 \%$, followed by SBI at $0.95 \%$, the Federal Bank at $0.89 \%$ and UBI at $0.70 \%$.In the F.Y. 2015-16 as per table 3, SBI's actual expenditure on CSR projects amounted to Rs. 143.92 crores which was $1.13 \%$ as against the mandatory requirement of Rs. 254 crores to constitute $2 \%$ of preceding three years' average profit. In case of UBI, just $0.37 \%$ was only spent constituting Rs.6.98 crores as against Rs. 38 crores on CSR activities. Federal Bank has spent Rs. 12.30 crores constituting $1.38 \%$ as against Rs. 18 crores. However, HDFC Bank alone had spent Rs.194.81 crores constituting $2.34 \%$ as against 2\% legal requirement to the tune of Rs. 166 crores only.

Among the select banks, HDFC Bank ranked first in CSR spending at $2.34 \%$, followed by The Federal Bank Ltd at $1.38 \%$, State Bank of India at $1.13 \%$ and Union Bank of India at $0.37 \%$.

Hence it is concluded that only HDFC Bank had achieved the statutory requirement of $2 \%$ of netprofit for CSR activities during the financial year 2015-16, while the remaining select banks failed to achieve the legal requirement of $2 \%$. However, except Union Bank of India, all other select banks improved their spending on CSR activities during 2015-16 as compared to the previous year. 


\section{Analysis and Interpretation of Perception of Bankers and Beneficiaries Relating to CSR}

To find out and study the issues related to CSR that needed immediate attention of Indian commercial banks from the point of view of employees and beneficiaries respectively, the respondents were asked to rate in a scale of 1 to 5 with 1 as the lowest and 5 as the highest. The mean score of the questions related to various issues for all 360 employees and 120 beneficiaries was found out, based on which the mean percentage score of each issue was calculated. This score was classified into four groups as 'Low Priority' if the mean percentage score was less than 35 per cent, 'Average Priority' if the mean percentage score was between 35 and 50 per cent, 'Medium Priority' if the mean percentage score lied in the interval of 50 to 75 per cent and 'High Priority' if the mean percentage score was above 75 per cent. Table 4 portrays the issues which need the immediate attention of Indian commercial banks, as the mean percentage score was above $75 \%$ in all the priority issues related to CSR.

Table 4: Issues which Need Indian Commercial Banks' Attention

\begin{tabular}{|l|l|l|l|l|l|}
\hline \multirow{2}{*}{ Priority Issues } & \multicolumn{2}{|l|}{ Employes } & \multicolumn{2}{l|}{ Beneficiaries } & \multirow{2}{*}{ Rating } \\
\cline { 2 - 6 } & Mean & MPS $^{*}$ & Mean & MPS $^{*}$ & High \\
\hline $\begin{array}{l}\text { Upliftment of } \\
\text { Community }\end{array}$ & 4.91 & 98.17 & 4.95 & 99.0 & High \\
\hline $\begin{array}{l}\text { Promotion of } \\
\text { Education }\end{array}$ & 4.85 & 97.00 & 4.98 & 99.5 & High \\
\hline $\begin{array}{l}\text { Environment } \\
\text { Conservation }\end{array}$ & 4.77 & 95.33 & 4.73 & 94.5 & High \\
\hline $\begin{array}{l}\text { Combating } \\
\text { Diseases }\end{array}$ & 4.83 & 96.50 & 4.80 & 96.0 & High \\
\hline $\begin{array}{l}\text { Child Welfare/ } \\
\text { Women } \\
\text { Empowerment }\end{array}$ & 4.97 & 99.33 & 4.98 & 99.5 & High \\
\hline Human Rights & 4.66 & 93.17 & 4.55 & 91.0 & High \\
\hline $\begin{array}{l}\text { Employment of } \\
\text { Differently Abled }\end{array}$ & 4.98 & 99.67 & 4.98 & 99.5 & High \\
\hline $\begin{array}{l}\text { Enhancement of } \\
\text { Vocational Skills } \\
\text { of Youth in Rural } \\
\text { Areas }\end{array}$ & 4.93 & 98.67 & 4.95 & 99.0 & High \\
\hline
\end{tabular}

Source: Computed from primary data

${ }^{*}$ Mean Percentage Score
As per Table 4, among the high priority issues related to CSR 'Employment of Differently Abled' should be given the top most priority according to employees' perspective since its mean percentage score of 99.67 was the highest. Whereas, Beneficiaries consider 'Promotion of Education', 'Child Welfare/Women Empowerment' and 'Employment of Differently Abled' as the three equal issues of top most priority that require immediate attention of the Indian commercial banks related to CSR as the mean percentage score of 99.5 each was the highest.

\section{Conclusion}

The study has divulged that though the Indian Banks are making efforts in CSR areas, still the initiatives need more thrust. Most of the banks are not even meeting the regulatory requirements. The current cap for annual donation of $1 \%$ (0.75\% for Normal donations and $0.25 \%$ for National Donations) of previous year's published profit set by RBI on banks should be reconsidered to be in line with Section 135 of Companies Act, 2013. RBI should be more stringent in issuing guidelines pertaining to setting apart of funds for CSR initiatives by banks. The banks have focused on the community welfare and farmers' welfare programs but the efforts for women welfare and education are not sizeable. This study might be useful for understanding the position of Indian commercial banks when CSR activities are concerned. The study has a scope of further research where the CSR performance of banks can be related to their financial performance.

\section{References}

1. UNIDO - United Nations Industrial Development Organization; 2007. www.unido.org. Retrieved $4^{\text {th }}$ April 2017. Available from: http://www.unido.org/csr/o72054. html.

2. Companies Act, 2013. 2nd edition. Lucknow; 2014.

3. Consultative Paper on Review of Corporate Governance Norms in India, SEBI.

4. Patel A. Corporate Social Responsibility: A Comparative Study of SBI and ICICI in India. International Journal for Innovative Research in Multidisciplinary Field. ISSN - 24550620. 2016 Oct; 2(10).

5. Sharma S, Agarwal A. Comparative study of Corporate Social Responsibility in Selected Public and Private Sector Banks. BRDV International Journal of Multidisciplinary Research. 2016; 1(3):10-7.

6. Pushpam VCJ, Karthi R, Daisy A. Corporate Social Responsibility of Banks in India. International Journal of Scientific and Research Publications. 2015 Apr; 5(4). 
7. Sharma E, Mani M. Corporate Social Responsibility: An Analysis of Indian Commercial Banks. AIMA Journal of Management \& Research; 2013 Feb.

8. Ayobami AP, Ofoegbu OE. Impact of Corporate Social Responsibility on Banking Performance in Nigeria. Journal of US-China Public Administration. 2012; 9(4):374-83.

9. Shirley Y. The Role of Banks in Corporate Social Responsibility. Journal of Applied Economics and Business Research. 2011; 1(2).

10. Kostyuk AN, Mozghovyi Y, Riabichenko DA, Govorun DA, Lapina Yu. Corporate Social Responsibility in Banks: An International Overview; 2014.

11. Khan Md, Habib HUZ. The Effect of Corporate Governance Elements on Corporate Social Responsibility (CSR) Reporting- Empirical Evidence from Private Commercial Banks of Bangladesh. International Journal of Law and Management; 2010. p. 82-109.

12. Annual Report; 2014 Apr 1. Available from: www.sbi.co.in

13. Annual Report; 2014 Apr 1. Available from: www.unionbankofindia.co.in
14. Annual Report; 2014 Apr 1. Available from: www.federalbank.co.in

15. Annual Report; 2014 Apr 1. Available from: www.hdfcbank. com

\section{Other References}

16. Business Responsibility Report; 2012. http://www.bseindia. com/. Retrieved 14 April 2017. Available from: http://www. bseindia.com/downloads/whtsnew/file/SEBI_BRR.

17. Bahl E. An overview of CSR Rules under Companies Act 2013; 2014 Mar 10. Avialable from www.business-standard.com: http://www.business- standard.com/article/companies/anoverview-of-csr-rules-under-Companies-Act-2013.

18. Report on Trend and Progress of Banking in India; 2013 Jun 30. Retrieved June 2, 2014, Available from: http://rbidocs. rbi.org.in/rdocs/Publications/PDFs/0RTP21112013_F.pdf

19. Avaialble from: www.rbi.org

20. Availabe from: www.sebi.org 